\title{
Rainfall, Temperature, and Forage Dynamics Affect Nutritional Quality of Desert Mule Deer Forage
}

\author{
Jason P. Marshal, ${ }^{1}$ Paul R. Krausman, ${ }^{2}$ and Vernon C. Bleich ${ }^{3}$ \\ Authors are ${ }^{1}$ Graduate Research Associate and ${ }^{2}$ Professor, School of Natural Resources, University of Arizona, \\ Tucson, AZ 85721; and ${ }^{3}$ Senior Environmental Scientist, Sierra Nevada Bighorn Sheep Recovery Program, \\ California Department of Fish and Game, 407 W. Line St, Bishop, CA 93514.
}

\begin{abstract}
Forage quality affects physiological condition, population dynamics, habitat use, and distribution of ungulates. We studied how rainfall, temperature, forage biomass, and forage growth are related to water content, crude protein (CP), and in vitro drymatter digestibility (IVDMD) of some common forage species of desert mule deer (Odocoileus hemionus eremicus Mearns) in the Sonoran Desert, California. We established vegetation transects in desert washes to collect forage samples and to measure forage biomass, growth, rainfall, and temperature on a quarterly basis. Percent water and CP were positively associated with forage growth $(P<0.001)$ and with rainfall $(P \leq 0.025)$. There were positive relationships between IVDMD and forage growth $(P<0.001)$, forage biomass $(P<0.001)$, and the combination of temperature and rainfall $(P<0.001)$. These findings suggest that the highest quality landscapes for deer are those with rapidly growing forage where forage water, CP, and IVDMD are greatest. With the quantified relationships between rainfall, temperature, and forage characteristics presented here, the nutritional constituents for deer forage can be predicted.
\end{abstract}

\section{Resumen}

La calidad de forraje afecta la condición fisiológica, las dinámicas de poblaciones, el uso de hábitat, y la distribución de ungulados. Estudiamos como la precipitación, temperatura y la biomasa y crecimiento del forraje están relacionados al contenido de agua, proteína cruda (CP), y la digestibilidad in vitro de materia seca (IVDMD) de algunas especies de forraje comunes del venado bura del desierto (Odocoileus hemionus eremicus Mearns) en el desierto Sonorense de California. Establecimos transectos en la vegetación de arroyos para recoger muestras de forraje, y para medir la biomasa del forraje, el crecimiento, la precipitación, y la temperatura cada 3 meses. El porcentaje de agua y CP estuvieron asociados positivamente con crecimiento del forraje $(P<0.001)$ y la precipitación $(P \leq 0.025)$. Hubo relaciones positivas entre IVDMD y crecimiento del forraje $(P<0.001)$, la biomasa del forraje $(P<0.001)$, y la combinación de temperatura y de precipitación $(P<0.001)$. Estos resultados sugieren que los hábitats de mas alta calidad para los venados son aquellos con forraje creciendo rápidamente donde el contenido de agua, CP, y la IVDMD son mayores. Con las relaciones cuantificadas entre la lluvia, temperatura y características del forraje presentadas aquí se puede predecir los constituyentes nutricionales del forraje para el venado.

Key Words: California, Odocoileus hemionus eremicus, plant growth, plant biomass, Sonoran Desert

\section{INTRODUCTION}

The nutritional quality of ungulate forage plants changes with season (Rautenstrauch et al. 1988; Renecker and Hudson 1988; Bleich et al. 1992; Alldredge et al. 2002). Nutritional quality is related to the phenological state of forage plants, and growth and quality of forage are influenced by environmental conditions that are influenced by changes in season. The importance of environmental conditions becomes clear during those seasons in which conditions vary substantially from normal and in which forage characteristics also vary substantially from normal. Although there are an abundance of studies demonstrating seasonal

The Rob and Bessie Welder Wildlife Foundation, the California Department of Fish and Game, Desert Wildlife Unlimited, the Imperial County Fish and Game Commission, and The University of Arizona School of Natural Resources provided funding and logistical support. Correspondence: Jason Marshal, School of Natural Resources, University of Arizona, Tucson, AZ 85721-0043. Email: jmarshal@ag.arizona.edu

Manuscript received 20 January 2004; manuscript accepted 17 October 2004. changes in forage quality for wildlife, rarely has nutritional quality been related directly to the environmental factors that accompany seasons. In arid environments, such as the Sonoran Desert, driving factors are precipitation and temperature (NoyMeir 1973). They and their effects on forage quality vary widely, producing a range of conditions over which to measure environmental effects on forage quality.

Nutritional quality of forage is an important aspect of forage availability and habitat quality (Wallmo et al. 1977; Hobbs and Swift 1985) and can influence physiological condition, reproduction, and survival of ruminants (Parker et al. 1999). Rautenstrauch et al. (1988) summarized several functions served by knowing forage quality: to identify limiting factors, to compare habitats, to evaluate habitat-management practices, to estimate carrying capacity, to identify periods of nutritional stress, and to identify important forage species. For the most part, efforts to describe forage characteristics for ungulates in the Sonoran Desert have involved seasonal summaries of various measurements of forage nutrient content or indices of quality. A further critical step is to understand how forage characteristics are 
affected by environmental factors and to predict forage quality and availability based on environmental conditions. All the functions summarized by Rautenstrauch et al. (1988) would benefit from understanding causal relationships between environment and forage.

Rautenstrauch et al. (1988) and Krausman et al. (1990) have described forage quality for mule deer (Odocoileus hemionus L.) in the Sonoran desert; however, these studies occurred in regions of the Sonoran desert that receive greater rainfall than southeastern California, an area for which there is no information on forage quality for mule deer. Furthermore, there have been no attempts to relate environmental variables directly to forage quality for mule deer in the Sonoran Desert. Our objectives were to estimate nutritional quality of some common forage plants for desert mule deer (O. h. eremicus Mearns) in southeastern California, and to determine how nutritional quality was related to rainfall, temperature, forage biomass, and forage growth.

\section{MATERIALS AND METHODS}

\section{Site Description}

Our study occurred from October 2000 to December 2002 in the Lower Colorado River Valley subdivision of the Sonoran Desert, eastern Imperial County, California (lat $33^{\circ} 00^{\prime} \mathrm{N}$, long $\left.114^{\circ} 45^{\prime} \mathrm{W}\right)$. Range in monthly mean temperatures was $6^{\circ}-36^{\circ} \mathrm{C}$, with summer maxima frequently exceeding $45^{\circ} \mathrm{C}$, and range in annual rainfall was 4-216 mm (mean $73 \mathrm{~mm}, 1914-2002$; Imperial Irrigation District, Imperial, California, unpublished data). Terrain in the area was varied but was primarily of 3 types: mountains, piedmont, and flats (Andrew 1994). Vegetation associations in our study area were typical for the Lower Colorado River region (Turner 1994). Common plants were burro-weed (Ambrosia dumosa [Gray] Payne.), creosote bush (Larrea tridentata [Sessé \& Moç ex DC.] Cov.), brittlebush (Encelia farinosa Gray ex Torr.), ocotillo (Fouquieria splendens Engelm.), palo verde (Cercidium floridum Benth.), desert-ironwood (Olneya tesota Gray), catclaw (Acacia greggii Gray), and cholla and prickly pear (Opuntia spp.). Although highly variable from year to year, winter tended to be cool-rainy (January-March), spring hot-dry (April-June), summer hotrainy (July-September), and autumn cool-dry (OctoberDecember). Andrew (1994) described the area in detail.

\section{Data Collection}

We collected plant samples for nutritional analysis from 22 sites established for another study (Marshal et al. 2005), at which there were measurements of rainfall and forage biomass and growth. Locations for sites were selected randomly from 1-km universal transverse mercator grids covering the study areas. We established a transect that followed the xeroriparian vegetation along the edge of the nearest wash. Transects occurred in mountain ( 3 sites), piedmont (13 sites), and flat terrain (6 sites) and included washes having a range of sizes (1-1 $000 \mathrm{~m}$ in width). We collected forage samples within $50 \mathrm{~m}$ of, but off, the transect to avoid influencing forage biomass on the transect. During quarterly sampling visits, there were attempts to collect $\geq 150 \mathrm{~g}$ from $\geq 10$ individual plants (i.e., 1 composite sample) of each of 7 major forage species, based on species found in mule deer fecal pellets collected in the area before this study (Marshal et al. 2004). Forage species were chosen that tended to occur in the diet year-round: desert-ironwood, mesquite (Prosopis glandulosa Torr.), burro-weed, brittle-bush, desert trumpet (Eriogonum inflatum Torr. \& Frém.), krameria (Krameria grayi Rose \& Painter), and fairy duster (Calliandra eriophylla Benth.). No ground-cover species (i.e., grass or forbs) were included because they occurred in our study area only after abnormally high rainfall (Marshal et al. 2005) and could not be reliably collected in all quarters. Also, seasonal scarcity made it difficult to collect $\geq 150 \mathrm{~g}$ of a single forage species in every quarter. We placed samples in paper bags and weighed them immediately after collection with a spring scale (Pesola, Baar, Switzerland). Forage samples were dried at approximately $60^{\circ} \mathrm{C}$ to a constant mass, using the final mass to estimate water content. These dried samples were then sent to the Wildlife Habitat Laboratory in Pullman, Washington. Samples were analyzed to determine percent crude protein (CP) and percent in vitro dry-matter digestibility (IVDMD).

To measure forage biomass at each wash site, we placed 40 plots $(1 \times 1 \times 2 \mathrm{~m}$ high $)$ on each transect every $20 \mathrm{~m}$ after a random start point, with a rain gauge near the middle of the transect. In each gauge, we put $2 \mathrm{~cm}$ of mineral oil to prevent evaporation of rainwater and a screen to exclude insects. At each quarterly visit, forage biomass was measured and rain gauges were checked. In each plot, we measured browse biomass (i.e., green leaves and twigs on shrubs) by a modification of the comparative yield method (Marshal et al. 2005). The amount of browse was visually assessed and assigned a rank $0-4$. Zero represented a plot with no browse (either completely empty or stems with no leaves or twigs), 1 a plot $25 \%$ full of browse, 2 a plot $50 \%$ full of browse, 3 a plot $75 \%$ full of browse, and 4 a plot $100 \%$ full of browse. We clipped green leaves and current-annual-growth twigs from $\geq 6$ plots for each rank to convert ranks to dry biomass (67 total). Ground-cover biomass was measured with similar methods. Plot height was $50 \mathrm{~cm}$, and we assigned 1 rank value for every $10 \mathrm{~cm}$ average height of ground-cover plants contained in the plot up to $50 \mathrm{~cm}$ (maximum rank 5). As for browse, we converted ground-cover ranks to dry biomass with 1-4 clipped ground-cover plots for each rank (11 total); sample size for this regression was limited by scarcity of ground cover during the study. We used the transect data to estimate forage biomass in the wash. Forage growth was calculated as forage biomass measured the previous visit to a transect subtracted from that measured during the current visit.

We adjusted forage growth estimates for potential effects of off-take by large herbivores with moving enclosures and by comparing forage growth in enclosed (i.e., protected) plots to forage growth in unenclosed (i.e., exposed) plots (Marshal et al. 2005). Shrub or shrub sections were protected from largemammal herbivory, and the protected shrubs were compared with similar shrubs (i.e., same species and similar biomass) that were marked but not enclosed. We chose plants that covered the range of browse biomass ranks $1-4$. Each enclosure consisted of $2 \times 4 \mathrm{~m}$ of steel livestock fence with $5-\times 10-\mathrm{cm}$ mesh, and protected a space $1 \times 1 \mathrm{~m}$ and $2 \mathrm{~m}$ high. Once we selected a shrub pair, we estimated browse biomass of each shrub using the modified comparative yield method, then we randomly selected 1 of the shrubs to enclose. We returned to each pair after 3 months to measure browse biomass of each shrub and determine the difference between shrubs in an enclosedunenclosed pair. At that time, a new pair of shrubs were selected 
Table 1. Nutritional quality of 7 species of deer forage in Imperial County, California, 2000-2002.

\begin{tabular}{|c|c|c|c|c|c|c|c|c|}
\hline \multirow[b]{2}{*}{ Species } & \multirow[b]{2}{*}{ Quarter } & \multirow[b]{2}{*}{ Availability $^{1}$} & \multicolumn{2}{|c|}{$\%$ Water $^{2}$} & \multicolumn{2}{|c|}{$\% \mathrm{CP}^{3}$} & \multicolumn{2}{|c|}{$\%$ IVDMD $^{4}$} \\
\hline & & & Mean & SE & Mean & SE & Mean & SE \\
\hline \multirow[t]{4}{*}{ Brittle-bush (Encelia farinosa Gray ex. Torr.) } & January-March & $2 / 2$ & 68.33 & 1.83 & 18.63 & 0.06 & 70.04 & 3.11 \\
\hline & April-June & $2 / 2$ & 57.02 & 17.69 & 15.20 & 4.62 & 62.67 & 7.90 \\
\hline & July-September & $3 / 2$ & 70.65 & 9.44 & 23.09 & 5.93 & 67.44 & 2.63 \\
\hline & October-Dececember & $3 / 3$ & 63.93 & 7.09 & 17.12 & 2.49 & 70.01 & 3.93 \\
\hline \multirow[t]{4}{*}{ Burro-weed (Ambrosia dumosa [Gray] Payne.) } & January-March & $2 / 2$ & 63.98 & 1.87 & 17.07 & 3.07 & 73.08 & 4.18 \\
\hline & April-June & $2 / 2$ & 55.23 & 18.28 & 14.76 & 7.73 & 65.71 & 8.32 \\
\hline & July-September & $2 / 2$ & 45.78 & 12.93 & 10.68 & 2.23 & 57.49 & 4.81 \\
\hline & October-December & $5 / 3$ & 66.69 & 3.04 & 17.53 & 2.02 & 68.99 & 2.78 \\
\hline \multirow[t]{4}{*}{ Desert-ironwood (Olneya tesota Gray) } & January-March & $2 / 2$ & 50.90 & 3.50 & 16.74 & 1.08 & 57.60 & 5.31 \\
\hline & April-June & $2 / 2$ & 55.65 & 8.28 & 15.92 & 3.87 & 64.14 & 5.24 \\
\hline & July-September & $2 / 2$ & 60.12 & 2.38 & 18.06 & 0.67 & 48.37 & 5.80 \\
\hline & October-December & $3 / 3$ & 56.32 & 1.39 & 16.81 & 0.98 & 58.71 & 1.93 \\
\hline \multirow[t]{4}{*}{ Desert Trumpet (Eriogonum inflatum Torr. \& Frém.) } & January-March & $2 / 2$ & 53.87 & 19.25 & 11.50 & 5.10 & 32.59 & 4.72 \\
\hline & April-June & $2 / 2$ & 55.09 & 19.60 & 12.02 & 4.72 & 40.69 & 11.60 \\
\hline & July-September & $1 / 2$ & 43.67 & - & 8.04 & - & 24.05 & - \\
\hline & October-December & $3 / 3$ & 65.12 & 6.20 & 16.16 & 2.76 & 31.49 & 1.78 \\
\hline \multirow[t]{4}{*}{ Fairy Duster (Calliandra eriophylla Benth.) } & January-March & $1 / 2$ & 50.79 & - & 20.71 & - & 37.13 & - \\
\hline & April-June & $2 / 2$ & 45.13 & 7.04 & 16.91 & 2.85 & 30.04 & 0.46 \\
\hline & July-September & $2 / 2$ & 53.25 & 14.25 & 21.03 & 8.65 & 41.72 & 2.18 \\
\hline & October-December & $3 / 3$ & 42.44 & 5.55 & 16.51 & 2.30 & 34.51 & 1.25 \\
\hline \multirow[t]{4}{*}{ Krameria (Krameria grayi Rose \& Painter) } & January-March & $2 / 2$ & 51.02 & 1.48 & 10.97 & 0.45 & 47.01 & 1.83 \\
\hline & April-June & $2 / 2$ & 50.24 & 8.67 & 10.83 & 3.53 & 44.49 & 2.19 \\
\hline & July-September & $2 / 2$ & 38.20 & 1.44 & 8.55 & 0.16 & 39.60 & 5.57 \\
\hline & October-December & $3 / 3$ & 48.39 & 4.23 & 10.62 & 1.20 & 42.41 & 1.01 \\
\hline \multirow[t]{4}{*}{ Mesquite (Prosopis glandulosa Torr.) } & January-March & $2 / 2$ & 58.70 & 13.67 & 24.05 & 10.42 & 58.89 & 3.03 \\
\hline & April-June & $2 / 2$ & 49.40 & 0.03 & 17.86 & 0.15 & 52.44 & 0.09 \\
\hline & July-September & $2 / 2$ & 48.15 & 0.94 & 17.02 & 0.44 & 56.76 & 1.55 \\
\hline & October-December & $3 / 3$ & 44.95 & 1.30 & 14.92 & 0.31 & 55.10 & 1.14 \\
\hline
\end{tabular}

${ }^{1}$ No. quarterly composites in average/no. quarters during the study.

${ }^{2}$ Percentage of fresh mass.

${ }^{3}$ Crude protein, percentage of dry mass.

${ }^{4}$ In vitro dry-matter digestibility, percentage of dry mass.

to allow for possible compensatory plant growth (McNaughton 1983), and the enclosures were moved to these new shrubs to repeat the process. We placed enclosures at 5 sites throughout the study area. At each site were 2-3 pairs of enclosedunenclosed shrubs, and sites were visited over 4 quarters (50 pairs total). If a difference in biomass occurred within a pair, we attributed this to off-take by large herbivores (i.e., mostly mule deer, but also potentially bighorn sheep [Ovis canadensis Shaw] and feral ass [Equus asinus L.]). Because ground cover was almost always absent during our study, no similar movingenclosure experiment was done for ground-cover growth. Temperature data came from the Yuma Proving Ground weather station, Arizona (20 km from the study area; http:// www.ncdc.noaa.gov/oa/climate/climatedata.html). Plant nomenclature follows Munz (1974).

\section{Data Analysis}

We looked for relationships between explanatory environmental variables (i.e., rain, temperature, biomass, and growth) and response nutritional variables ( $\%$ water, $\% \mathrm{CP}, \%$ IVDMD) using multiple linear regression. To meet distribution assumptions, all percentages were transformed by converting them to proportions, dividing each proportion by 1 minus that proportion, and calculating the natural logarithm of that ratio (i.e., we calculated the log odds) (Ramsey and Shafer 2002). We used forage species as a blocking variable; we report results after removing variation explained by forage species. To interpret estimates of regression parameters, regression slopes were back transformed by calculating the antilog of the odds ratios. We did not recalculate slopes with respect to the original proportions; parameter estimates described changes in the median ratio of a forage component to the part of the forage without that component (e.g., proportion $\mathrm{CP} /[1$ - proportion $\mathrm{CP}])$, and how that median ratio changed with the explanatory variable (Ramsey and Shafer 2002).

\section{RESULTS}

We collected 64 composite forage samples: brittle-bush (10), burro-weed (11), desert-ironwood (9), desert trumpet (8), fairy duster (8), krameria (9), and mesquite (9). Although not all 
Table 2. Mean rainfall, temperature, forage biomass, and forage growth at plant sample sites, Imperial County, California, 2000-2002.

\begin{tabular}{|c|c|c|c|c|c|c|c|c|c|}
\hline \multirow[b]{2}{*}{ Year } & \multirow[b]{2}{*}{ Quarter } & \multicolumn{2}{|c|}{$\begin{array}{l}\text { Rainfall } \\
(\mathrm{mm})\end{array}$} & \multicolumn{2}{|c|}{$\begin{array}{c}\text { Temperature } \\
\left({ }^{\circ} \mathrm{C}\right)\end{array}$} & \multicolumn{2}{|c|}{$\begin{array}{c}\text { Biomass } \\
\left(\mathrm{g} \cdot \mathrm{m}^{-2}\right)\end{array}$} & \multicolumn{2}{|c|}{$\begin{array}{c}\text { Growth } \\
\left(\mathrm{g} \cdot \mathrm{m}^{-2} ;(3\right. \\
\left.\text { months })^{-1}\right)\end{array}$} \\
\hline & & Mean & SE & Mean & SE & Mean & SE & Mean & SE \\
\hline 2000 & October-December & 15 & 2 & 18.8 & 1.7 & 28.2 & 6.4 & 18.5 & 5.1 \\
\hline \multirow[t]{4}{*}{2001} & January-March & 31 & 10 & 14.9 & 0.7 & 30.3 & 8.0 & 1.6 & 4.5 \\
\hline & April-June & 73 & 1 & 22.5 & 1.2 & 37.3 & 1.8 & 36.1 & 3.0 \\
\hline & July-September & 17 & 7 & 33.9 & 0.2 & 14.9 & 0.9 & -10.5 & 3.4 \\
\hline & October-December & 43 & 9 & 17.4 & 1.5 & 33.8 & 9.3 & 14.6 & 9.5 \\
\hline \multirow[t]{4}{*}{2002} & January-March & 9 & 2 & 14.5 & 1.0 & 36.3 & 7.9 & 14.6 & 4.4 \\
\hline & April-June & 1 & 1 & 27.1 & 1.2 & 6.3 & 1.9 & -8.5 & 4.1 \\
\hline & July-September & 16 & 4 & 32.4 & 0.5 & 15.6 & 5.0 & 7.5 & 4.6 \\
\hline & October-December & 24 & 4 & 21.0 & 1.4 & 33.3 & 5.8 & 26.6 & 4.3 \\
\hline
\end{tabular}

species were available throughout the year, every species was available in $\geq 1$ quarter in $\geq 1$ year (Table 1 ). Percent water, $\%$ $\mathrm{CP}$, and \% IVDMD varied from species to species and quarter to quarter (Table 1). Brittle-bush was highest overall in \% water (65.44 \pm 3.74 [SE], $\left.F_{6,57}=3.31, P=0.007\right), \%$ IVDMD $\left(67.78 \pm 2.05, \quad F_{6,57}=43.90, \quad P<0.001\right), \quad$ and $\% \quad C P$ $\left(18.83 \pm 1.64, F_{6,57}=3.33, P=0.007\right)$.

There was a positive relationship between water in forage (Table 1) and forage growth (Table 2; Fig. 1). Median ratio of forage water increased 1.0167 times for every $1 \mathrm{~g} \cdot \mathrm{m}^{-2} \cdot(3$ months) ${ }^{-1}$ increase in forage growth (back-transformed slope; Table 3). A separate regression between ratio of forage water and rainfall also revealed a positive relationship. Median ratio of forage water increased 1.0074 times for every $1 \mathrm{~mm}$ increase in quarterly rainfall (back-transformed slope; Table 3). Because rainfall and forage growth were correlated $(R=0.55)$, they had a similar influence on forage water. Higher median ratios of $\mathrm{CP}$ were associated with higher forage growth (back-transformed

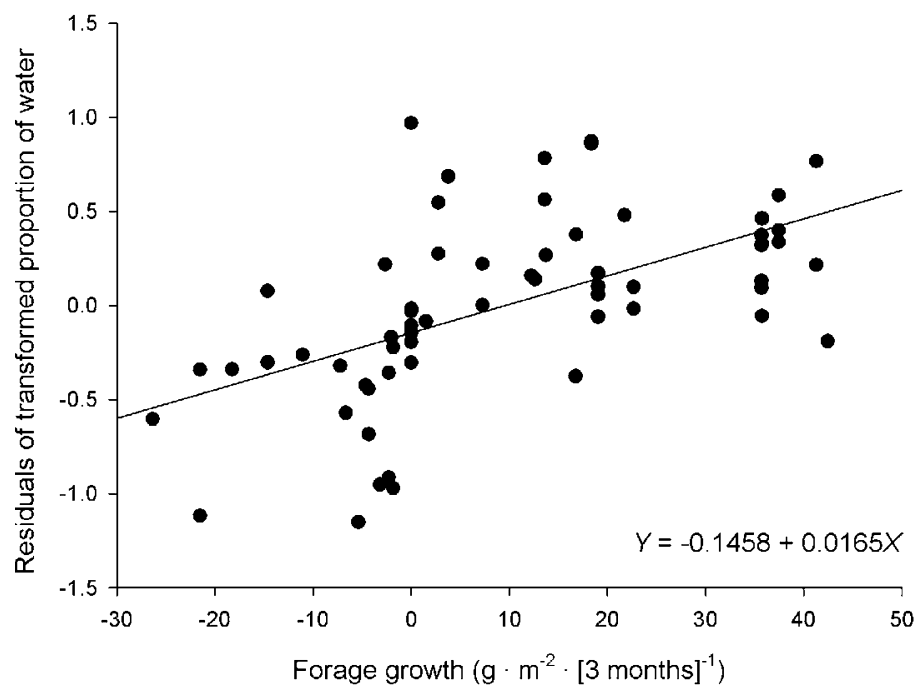

Figure 1. Relationship between forage growth and log-odds-ratiotransformed proportion of water $\left(n=55, R^{2}=0.54\right)$, after removal of variation explained by forage species, in 7 species of desert mule deer forage plants, Imperial County, California, 2000-2002.
Table 3. Results of regression analysis after removal of variation explained by forage species, with log odds of forage nutritional characteristics (\% water, \% crude protein [CP], and \% in vitro drymatter digestibility [IVDMD]) as response variables and rainfall, temperature, plant growth, and plant biomass as explanatory variables, Imperial County, California, 2000-2002.

\begin{tabular}{llrrrrrr}
\hline Response & Explanatory & Coefficient & SE & $t$ ratio & $P$ value & df & $R^{2}$ \\
\hline \% Water & Growth & 0.0167 & 0.0030 & 5.42 & $<0.001$ & 48 & 0.54 \\
$\%$ Water & Rainfall & 0.0073 & 0.0024 & 3.00 & 0.004 & 56 & 0.37 \\
$\%$ CP & Growth & 0.0114 & 0.0023 & 4.91 & $<0.001$ & 48 & 0.54 \\
$\%$ CP & Rainfall & 0.0044 & 0.0019 & 2.30 & 0.025 & 56 & 0.36 \\
\% IVDMD & Growth & 0.0076 & 0.0019 & 3.96 & $<0.001$ & 48 & 0.86 \\
$\%$ IVDMD & Biomass & 0.0092 & 0.0022 & 4.11 & $<0.001$ & 48 & 0.86 \\
$\%$ IVDMD & Rainfall & 0.0032 & 0.0014 & 2.31 & 0.025 & 55 & 0.84 \\
& Temperature & -0.0097 & 0.0046 & -2.11 & 0.039 & & \\
\hline
\end{tabular}

slope $=1.0115$; Table 3; Fig. 2). In a separate regression, median ratio of CP increased 1.0044 times for every $1 \mathrm{~mm}$ increase in rainfall (back-transformed slope; Table 3). As with forage water, relationships of forage growth and rainfall to ratio of $\mathrm{CP}$ were similar.

Unlike water and $\mathrm{CP}$, both forage growth and forage biomass explained a large proportion of variation in ratio of IVDMD (Table 3). Median ratio of IVDMD increased 1.0077 times for every $1 \mathrm{~g} \cdot \mathrm{m}^{-2} \cdot(3 \mathrm{months})^{-1}$ increase in forage growth (back-transformed slope; Table 3, Fig. 3). In a separate analysis, ratio of IVDMD increased 1.0092 times for every $\mathrm{g} \cdot \mathrm{m}^{-2}$ increase in forage biomass (back-transformed slope). We also investigated effects of rainfall and temperature on IVDMD in a separate regression. After accounting for effects of temperature, ratio of IVDMD increased 1.0032 times for every $1 \mathrm{~mm}$ increase in quarterly rainfall. Temperature had a negative effect, decreasing the median ratio of IVDMD 0.9903 times for every $1^{\circ} \mathrm{C}$ increase in temperature, after accounting for effects of rainfall. Biomass and the combination of rainfall and

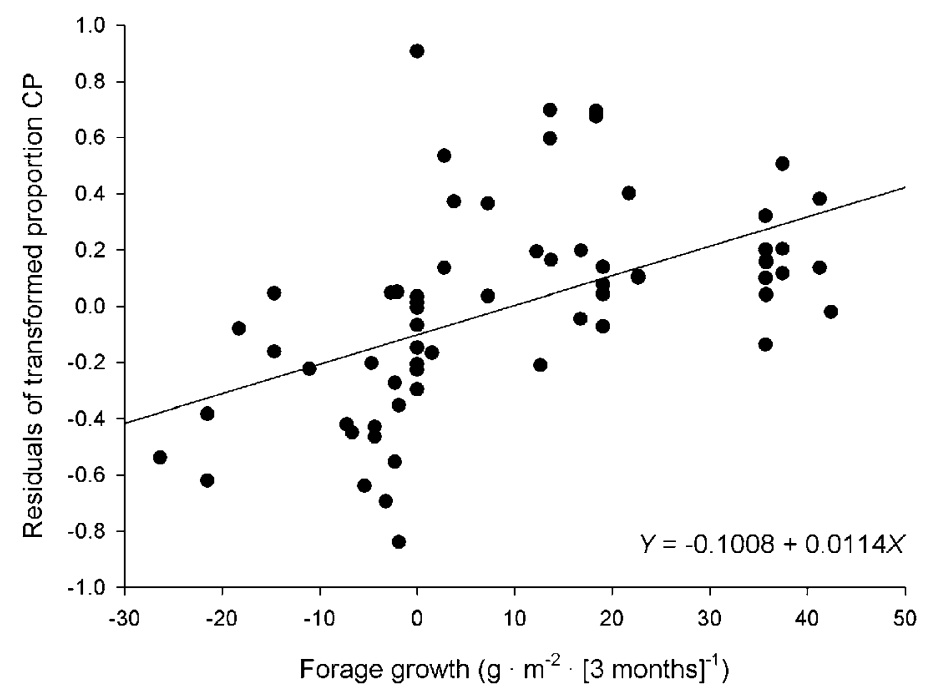

Figure 2. Relationship between forage growth and log-odds-ratiotransformed proportion of crude protein (CP) $\left(n=55, R^{2}=0.54\right)$, after removal of variation explained by forage species, in 7 species of desert mule deer forage plants, Imperial County, California, 2000-2002. 


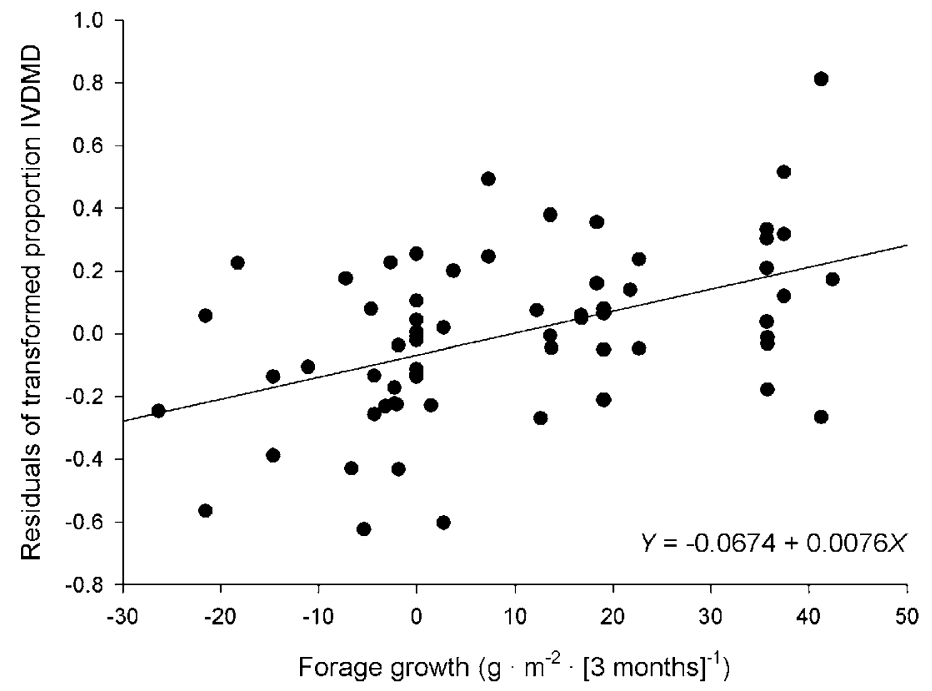

Figure 3. Relationship between forage biomass and log-odds-ratiotransformed proportion of in vitro dry-matter digestibility (IVDMD) ( $n=55, R^{2}=0.86$ ), after removal of variation explained by forage species, in 7 species of desert mule deer forage plants, Imperial County, California, 2000-2002.

temperature were correlated $(R=0.54)$ and, as mentioned before, rainfall and forage growth were correlated, which explained the similar relationships between these variables and IVDMD.

\section{DISCUSSION}

Forage nutritional quality is an important aspect of explaining the ecology of wild ungulates, from determining physiological condition of individuals (White 1978) to affecting distribution of animals across a landscape (Fryxell 1991). In the Sonoran Desert of California, nutritional quality of forage is ultimately determined by rainfall and, in part, temperature (Table 3). Although patterns of rainfall and temperature changed seasonally, rainfall in this part of the Sonoran Desert was highly variable; very little rain fell in some years, even during rainy seasons (Marshal et al. 2005). For this reason, relating forage characteristics to seasons is probably not biologically realistic in our study area, and it became necessary to relate measures of forage quality directly to the environmental conditions with which they are associated.

Development of water sources for managing populations of desert ungulates continues to be a contentious issue in the US southwest (Rosenstock et al. 1999). A question frequently raised by wildlife managers is whether forage contains enough moisture that desert ungulates can meet their water requirements without standing water (Krausman and Czech 1998). Although we have no information on physiological requirements of desert mule deer for water, we can comment on water availability. We found that water content of deer forage was positively associated with forage growth and rainfall. This finding suggests that water is more available in forage when it is less limiting in the environment (i.e., during rainy seasons). Unfortunately, this means that, during conditions in which water is most scarce (April-June), water content of forage is generally low. This may partly explain observations of radiocollared deer in the study area that only are found close to wildlife water developments (i.e., catchments) during this water-limited time (Marshal et al., unpublished data). If the movement of deer toward catchments is in response to a drop in forage water content, it may indicate that water content is not sufficient to sustain mule deer.

The higher CP associated with higher rates of forage growth can be explained by the anabolic processes that occur during the production of plant tissues, processes that decrease as plants reach vegetative maturity (Greenwood and Barnes 1978). Our findings were consistent with those of other desert ungulate forage studies: protein content of forage tended to be lowest during seasons with low rainfall and, consequently, low forage growth (Rautenstrauch et al. 1988; Krausman et al. 1990; Bleich et al. 1992). Wallmo et al. (1977) used 7\% crude protein as an estimate of maintenance protein requirements for mule deer in Colorado. By comparison, the lowest \% CP value we collected was $6.4 \%$ for desert trumpet during Apr-June 2002, and $95 \%$ of the samples we collected contained $>7 \%$ crude protein. While this could suggest adequate protein in forage for maintenance of mule deer, several things may complicate this evaluation. For example, crude protein is based on total nitrogen in plant cells, whereas true protein represents $75 \%-85 \%$ of that total nitrogen (Robbins 1983). After adjusting for percent of true protein (by multiplying $\%$ CP by 0.8$),>85 \%$ of the samples met the $7 \%$ maintenance protein requirement suggested by Wallmo et al. (1977). Another complication is that protein available to a foraging ungulate is likely lower than total protein in plant cells because of the effects of plant secondary compounds on protein digestion (Mould and Robbins 1982). Because levels of plant secondary compounds differ between forage species, a simple estimate of crude protein might not reflect what actually is available to mule deer. Moreover, deer are generalist browsers that mix forage species in their diets to optimize nutrient intake while limiting toxic effects of plant secondary compounds (Mould and Robbins 1982). As a result, the picture of the availability of protein to deer is probably more complicated than what is reflected in an estimate of plant crude protein.

Our finding of higher rates of IVDMD associated with more rapid forage growth was common to many studies of ungulate forage. Digestibility generally decreases in plants as growth decreases and cell walls develop in plant tissues (Mould and Robbins 1982; Van Soest 1982). However, we also found a positive relationship between forage biomass and IVDMD, which is inconsistent with the effects of growth on IVDMD. Growth rate of forage decreases with increasing forage biomass (Marshal et al. 2005) because of increasing competition among plants for light and nutrients (Caughley 1976). Because digestibility is positively associated with growth rate (Fig. 3), IVDMD should have decreased with forage biomass. This inconsistent result could be an artifact of the frequency with which we visited forage sampling sites. Desert trees and shrubs responded quickly ( $<1$ week) to adequate rainfall by producing new foliage; however, die back of foliage in dry periods following that growth was considerably slower ( $>1$ month). By chance alone, we were more likely to sample plants during the die-back phase more often than during the growth phase. Because abundance decreased at the same time as digestibility, this could have caused an apparent positive relationship between 
digestibility and forage biomass. In temperate forested regions, there is usually 1 green-up episode, during which foliage abundance and digestibility increase early in the growing season, and then digestibility decreases as foliage becomes mature (Renecker and Hudson 1988). In the Sonoran Desert of California, there was generally no prolonged period of abundant foliage; it either increased or decreased in response to increases or decreases in rainfall (Marshal et al. 2005).

Forage characteristics have important consequences for habitat quality of mule deer in the Sonoran Desert. From our results, forage qualities changed in response to different environmental conditions, conditions that vary considerably over space $(1 \mathrm{~km})$ and time (weekly to monthly) (Marshal et al. 2005). Mule deer move in response to changes in forage conditions, but the manner in which they select areas is still under investigation. However, we propose hypotheses based on forage quality that may explain observations of deer movements in the study area. During the summer rainy season, rainfall events tend to produce strip rains, where a large amount of rain falls on an area about $1 \mathrm{~km}$ wide and several $\mathrm{km}$ long and little rain falls on adjacent areas. Strip rains produced a highly heterogeneous response in plant growth across the study area (Marshal et al. 2005) and a patchy distribution in forage biomass and quality. Deer should respond to this heterogeneity by selecting areas with rapidly growing plants, such as those in areas that recently received rainfall, because forage from those plants are high in water, protein, and digestibility. When rapidly growing forage is not available, deer should select areas of high forage biomass, where they can take advantage of forage of higher digestibility before plant biomass and digestibility decrease. When forage water decreases beyond a critical threshold, however, locations of catchments may become most important in determining deer distribution, and forage growth and biomass become secondary. A test of this hypothesis might be possible with the use of global positioning system telemetry collars, the evaluation of forage nutritional quality and biomass at measured mule deer locations, and the characteristics of forage in sites recently abandoned by mule deer and new sites they occupy. The timing of movements between sites should be quantifiable and predictable based on cues from forage characteristics.

\section{ACKNOWLEDGMENTS}

We thank W. Ballard, M. Fernandez-Gimenez, D. Lawrence, J. Pfister, and an anonymous reviewer for comments on previous drafts of this manuscript. This research was a cooperative effort between The University of Arizona School of Natural Resources, the California Department of Fish and Game (CDFG), the Imperial County Fish and Game Commission, and Desert Wildlife Unlimited. This is a contribution from the CDFG Deer Herd Management Plan Implementation Program and is contribution 625 of the Rob and Bessie Welder Wildlife Foundation and professional paper 043 of the Eastern Sierra Center for Applied Population Ecology.

\section{LITERATURE CITED}

Alldredge, M. W., J. M. Peek, And W. A. Wall. 2002. Nutritional quality of forages used by elk in northern Idaho. Journal of Range Management 55: 253-259.
Andrew, N. G. 1994. Demography and habitat use of desert-dwelling mountain sheep in the East Chocolate Mountains, Imperial County, California [thesis]. Kingston, RI: University of Rhode Island. $135 \mathrm{p}$.

Bleich, V. C., R. T. Bowyer, D. J. Clark, and T. O. Clark. 1992. An analysis of forage used by mountain sheep in the eastern Mojave Desert, California. Desert Bighorn Council Transactions 36:41-47.

Caughley, G. 1976. Wildlife management and the dynamics of ungulate populations. In: T. H. Coaker [ed.]. Applied biology. Volume I. London, UK: Academic Press. p 183-246.

FRYXELL, J. M. 1991. Forage quality and aggregation by large herbivores. American Naturalist 138:478-498.

Greenwood, D. J., and A. Barnes. 1978. A theoretical model for the decline in the protein content of plants during growth. Journal of Agricultural Science 91: $461-466$.

HobBS, N. T., AND D. M. SwIFt. 1985. Estimates of habitat carrying capacity incorporating explicit nutritional constraints. Journal of Wildlife Management 49:814-822.

Krausman, P. R., and B. Czech. 1998. Water developments and desert ungulates. In: J. M. Feller, and D. S. Strouse [eds.]. Environmental, economic, and legal issues related to rangeland water developments. Tempe, AZ: Arizona State University College of Law. p 138-154.

Krausman, P. R, L. L. Ordway, F. M. Whiting, and W. H. Brown. 1990. Nutritional composition of desert mule deer forage in the Picacho Mountains, Arizona. Desert Plants 10:32-34.

Marshal, J. P., V. C. Bleich, N. G. Andrew, and P. R. Krausman. 2004. Seasonal forage use by desert mule deer in southeastern California. Southwestern Naturalist 49:501-505.

Marshal, J. P., P. R. Krausman, and V. C. Bleich. 2005. Dynamics of mule deer forage in the Sonoran Desert. Journal of Arid Environments 60:593-609.

McNaughton, S. J. 1983. Compensatory growth as a response to herbivory. Oikos 40:329-336.

Mould, E. D., And C. T. Robisns. 1982. Digestive capabilities in elk compared to white-tailed deer. Journal of Wildlife Management 46:22-29.

Munz, P. A. 1974. A flora of Southern California. Berkeley, CA: University of California Press. 1086 p.

Noy-MeIR, I. 1973. Desert ecosystems: environment and producers. Annual Review of Ecology and Systematics 4:25-51.

Parker, K. L., M. P. Gillingham, T. A. Hanley, and C. T. Robbins. 1999. Energy and protein balance of free-ranging black-tailed deer in a natural forest environment. Wildlife Monographs 143.

Ramsey, F. L., And D. W. Schafer. 2002. The statistical sleuth: a course in methods of data analysis. 2nd ed. Pacific Grove, CA: Duxbury. $742 \mathrm{p}$.

Rautenstrauch, K. R., P. R. Krausman, F. M. Whiting, and W. H. Brown. 1988. Nutritional quality of desert mule deer forage in King Valley, Arizona. Desert Plants 8:172-174.

ReneCKer, L. A., And R. J. Hudson. 1988. Seasonal quality of forages used by moose in the aspen-dominated boreal forest, central Alberta. Holarctic Ecology 11: 111-118.

RoBBINS, C. T. 1983. Wildlife feeding and nutrition. Orlando, FL: Academic Press. $343 \mathrm{p}$.

Rosenstock, S. S., W. B. Ballard, and J. C. Devos, JR. 1999. Benefits and impacts of wildlife water developments. Journal of Range Management 52: 302-311.

Turner, R. M. 1994. Sonoran desertscrub. In: D. E. Brown [ed.]. Biotic communities: Southwestern United States and northwestern Mexico. Salt Lake City, UT: University of Utah Press. p 181-221.

VAN SOEST, P. J. 1982. Nutritional ecology of the ruminant. Corvallis, OR: 0 and B Books. $476 \mathrm{p}$.

Wallmo, O. C., L. H. Carpenter, W. L. Regelin, R. B. Gill, and D. L. Baker. 1977. Evaluation of deer habitat on a nutritional basis. Journal of Range Management 30:122-127.

WHITE, T. R. C. 1978. The importance of a relative shortage of food in animal ecology. Oecologia 33:71-86. 